transitions from higher to lowor atomic energy levels induced by the incident light. This represents negative dispersion since it opposes the effect of absorptive transitions from lower to higher levels. In retrospect this work appears as an important landmark on the long road from Einstein's conception of the ides of stimulatod omission in 1919 through the various radio froquency and micro. wave magnetic resonances which are dominated by the competition between stimulated emission and absorption, to crystal masers and finally, ending not far from the starting point, to tho helium-sensitized neon gas laser with its immonse possibilities for research and technologies.

Kopfermann's first work on nuclear hyperfine structure and isotope shift overlapped the final phases of his work on negative dispersion which involvod high-resolution tochniques. Working under the same roof with Hahn and Lise Meitner, and not far from the Einsteinturm in Potsdam whore Schüler had pioneered the hollow cathode cooled light source, he was naturally attracted to this very fruitful fiold of application of spectroscopy which in one form or another was to be his main intereat for the rest of his life.

A period in Bohr's Institute in Copenhagen, whore he collaborated with Rasmussen on a numbor of problems of hyperfine structure, had a profound infuence on him. $\mathrm{He}$ shared with Bohr an essential humility, epitomizod by the Nur um zu lernen (only in order to loarn), one of the many Bohrisms which Kopformann used to quote and to live by. Indeed, those fortunate to have worked with or under him will remember him, above all, as the true mentor and friend who guided them through their difficulties and whose deep insight into the essential physics beyond the immediate experimental problems inspired them to do their best creativo work.

On return to Berlin he became Privatdozent at the Univorsity, still continuing his work on nuoloar hyperfine structure and isotope shift in the Kaiser Wilhelm Institute, but later moved to Gustav Hertz's Institute at the Tochnischo Hochschule, Berlin. It was hero that he initiated projects on the separation of isotopes for nuclear spectroscopy which fitted in with Hertz's interests at the timo, and were carried out by Walcher and Paul, his faithful collaborators for the next ten years.

In 1937 he took up his first chair in the University of Kiel. In the difficult pre-war period and under the restricted conditions of a small University, the pace of experimental work had to slow down. Kopfermann utilizod this interval for writing his book on nuclear moments in which he showed a romarkable grasp of a subject which was then in its beginning, and a clear vision of its significance for the understanding of nuclear structure. So much so, that the Kernmomente of 1956-or its English version of 1958-was truly a second edition, unchanged in plan and conception but expandod to almost twice the size of the original book by the lucid and original presentation of all the new developments of the post-war era, such as nuclear resonance techniques.

The call to Göttingen which Kopfermann followed in 1942, to occupy the chair at the Second Physical Institute from which his great teacher, James Franck, had felt compelled to resign in 1933, must have filled Kopfermann with pride and sadness, for his attitude vis-dे-vis the Nazi régime was uncompromising and without reproach. His loyalty was to his frionds and to science, and there are many who will remember Kopfermann's active help with gratitude.

Göttingen, which had escaped serious destruction, became in the immediate post-war years a haven whore the elite of German science, v. Laue, Heisenberg, Weizsäcker, etc., congregated. It was during this period that, apart from notable work with Paul on the Lamb shift in helium, Kopfermenn made his most outstanding contribution to the study of nuclear structure. In collaboration with Brix, he discovered jumps in the relative isotope shift of heavy elements which ho related to the quadruple momont and deformation of the nuclei, ideas which led Aage Bohr and Mottelson to the dynamical modol of the nucleus. In the same period, Dehmelt and Krüger in auguratod under his inspiration the method of nuclear electric quadruple resonance which now, liko nuclear magnetic resonance, occupies an important place in the study of the oloctronic structure of molecules.

It may be less well known that Kopfermann initiated and supported research in puro nuclear physics, particularly nucloar photo effects. This goes back to the war-time, when very soon after Kerst's first publications he persuaded Paul to develop a betatron. The first machine was completed about the end of the War. Undaunted by the strict regulations of the military government which forbade its use for nuclear studios, Kopfermann collaborated with his medical colleagues on methods of diroct electron therapy which appeared very promising at the time. His fine article in the Ergebnisse der Exakten Naturwissenschaften on the "Elektronenschleuder" ("electron sling' for betatron, a valiant, but alas unsuccessful, atternpt to stem the flood of pseudo-Greek atrocities) reflects the enjoyment and active interest which Kopfermann took in these more technical developments.

Kopfermann's move to his last station marked the beginning of a more prosperous era so far as material support for scientific research in Germany was conoerned. Under his direction the Physical Institute at Heidelberg has developed into one of the best-equipped and mostproductive laboratories for the study of the nuelous by atomic spectroscopy, atomic beam methods, various typers of optical double resonance, by accelerators and other techniques of more strictly nuclear physios. Up to the last he took a very active part in the rosearches, inspiring and encouraging his devoted students and collaborators. To see so many of them in leading positions in univorsities and industry, eight in important chairs in Germany, two in chairs in tho United States, must have given him deep satisfaction. Although he shied away from official positions, his views commanded great respect, and in the background ho oxercised a beneficial influence on the higher direction of science and physios in Germany.

Kopfermann had many interests outside physics. To join in chambor music on his viola in a small circle of his colleagues and friends was his great joy and happinoss. The warm glow and youthful freshness of his personality endoarod him to all who met him. E. E. SCHNEIDER

\section{Prof. E. B. Moullin}

The death of Prof. Fric Balliol Moullin on September 18 at the age of seventy will have saddened many members of the electrical engineering profossion, and particularly those who were privileged to be old students of his at Cambridge or. Oxford.

$\mathrm{H}_{e}$ was born on August 10, 1893, at Sandbanks, near Swanage, and his later attachment to radio frequency measurements may have been influenced by the fact that his birthplace was within a fow hundred yards of the site of the first wireless mast set up in Britain by Marconi. $\mathrm{H}_{e}$ was educated privately and learned at home the mathematics which won him a scholarship at Downing College, Cambridge. $\mathrm{H}_{\theta}$ took first-class honours and was the John Winbolt Prizeman in the Mechanical Sciences Tripos. Owing to a breakdown in health he was unfit for military service in the First World War, but taught for part of this period at the Royal Nuval Collogo, Greenwich, before returning to Cambridge in 1919 as university lecturer in engineering, and member of King's College.

At the time radio -or wireless as it was then calledwas in its infancy, and Moullin wes among the first to devise accurate means of measuring the characteristics of components, circuits and radiating systems for use at radio froquonsies. His invention in the early 1920 's of the 
valve voltmeter, and the first edition of his book, Radio Frequency Measurements, oxercised a profound influence on the early development of the subject. However, his interests wero not confined to radio. He taught over the whole field of electrical engineoring and mado contributions outside it, such as the devising of a torsiometer for the measuring of torsion in rotating shafts, with which he experimented on the liner Franconia during an Atlantic crossing.

The establishment of a readership in engineering science attracted him to Oxford and to Magdalen Collogo in 1929, and he in turn attractod to its small engineering school as research students a succession of men who benefited enormously from his stimulating inquisitiveness and incisive search for understanding. Ho supervised programmes of research into the properties of dielectrics, the mechanisms of electrical noise and the characteristies of aerial systoms, and was always at pains to onsure that his own publications in these fiolds-which were manydid not dotract from those of his young colloagues, to whom ho gave intimate personal attention.

It was perhaps unfortunate that his services were lost to teaching during the Second World War, but he was anxious to play a direct part in the developmont of now radio and radar devices, and, in 1939, he joined the Admiralty Signals Establishment at Portsmouth for this purpose. In 1942 ho transferred to the Research Laboratories of Metropolitan Vickers in Manchester, and found many opportunities there to apply his outstanding mathematical and experimontal abilities to similar onds.
At the end of the War ho returned to Cambridge as the first professor of electrical ongineering and as a Fellow of King's College, and he then devoted himself to the reorganization of the teaching arrangements in his subject and the preparation of books on aerial systems and on electrical machines. Fle also gave unsparingly of his time to the work of the Institution of Electrical Engineers, and was its president during the 1949-50 session. He was elected to honorary membership of the Institution earlier this yoar.

Moullin's contributions to toaching and research spanned a period of quite fantastic change. During this period sevoral new branches of his subject emerged, became of considerable industrial importance, and demanded oducational attention. He searched continually for the interrelationships between these specialist fields and for means of presenting thom as components in a coherent whole, and his efforts were of great assistance to others who, like himsolf, were not finding this an easy matter.

Eric Moullin was extremely proud of his Guernsey ancestry and was overjoyed when, in 1947, he inhorited the Fiof des Eperons as great-great-groat-grandson of Jean Rougier. In this capacity it fell to him to pay his foudal homage when the Queon visited the Island in 1957, and to offer to Her Majesty, on bended knoe, a pair of golden spurs dating back to 1675. As Seigneur do Fief des Eperons he was hereditary head of the feudal court, comprising a Seneschal and a Douzaino of honost men, which had powors over boundaries and other matters of land in Guernsey.

WILLIS JACKSON

\section{NEWS and VIEWS}

\section{David Rivett Memorial Lecture}

Folsowing the death in April 1961 of Sir David Rivett, formorly chief executive officor and lator chairman of the Australian Council for Scientific and Industrial Research (Nature, 190, 958; 1961), soveral of his colleagues proposed that a suitablo memorial should be established to help prosorve the vigorous stimulus of his leadership. Sir David, more than any other person, was responsible for establishing the pattern of the Commonwoalth Sciontific and Industrial Research Organization as it is known to-day. Those who worked with Sir David felt that the most fitting memorial to him would be the establishment of a momorial fund which could be used to finance a formal lecture to be deliverod in one or other of the capital cities of Australia every two years by a man who had reached the highest ranks of achievemont in sciontific research. An appeal for contributions was quickly over-subscribod and a memorial fund ostablished. The first memorial lecture, "Development of Modern Scienco", was delivered at the Wilson Hall, University of Melbourne, on September 5 by Sir Howard Florey, president of the Royal Socioty and Nobel laureate (p. 397 of this issuo of Nature).

\section{Deputy Controller of Aircraft, Ministry of Aviation: Mr. H. Davies, C.B.}

Mr. H. Davies has beon appointed deputy controllor of aircraft (research and development), Ministry of Aviation, in succession to Mr. M. B. Morgan, who was recently appointed controller of aircraft (soe Nature, 199, 431; 1963). Mr. Davies was born at Aberdare, South Walos, in 1912, and was oducated at Aberdare Grammar School and University of Walos (Cardiff). $\mathrm{He}$ entored the Scientific Civil Sorvice in 1936 and servod at the Royal Aircraft Establishment until 1942. During the period 1942-46 he was employed at Headquarters on the long-term planning of Air Staff Requirements. He then roturned to the Royal Aircraft Establishment and in 1948 became Superintendent of the Aero Flight Division. Ho was promoted to deputy chief scientific officer in 1952 and appointed chief superintendent, Aoroplano and Armament Experimental Establishment, Boscombe Down, where he romained until 1955, whon he was promoted to chief scientific officer and seconded to the Air Ministry as scientific adviser. In 1956 he was appointed director genoral of scientific research (air), and since 1959 ho has been serving as deputy director (air) at the Royal Aircraft Establishment, Farnborough.

Mr. L. F. Nicholson

Mr. L. F. Niciolson has boen appointed deputy diroctor (air) at the Royal Aircraft Establishment, Farnborough, in succession to Mr. H. Davies. Mr. Nicholson was born at Watford in 1918, and was educated at Taunton School and King's College, Cambridge. Ho entered the Scientific Civil Service in 1939 and served at the Royal Aircraft Establishment, Farnborough, until 1959. He became superintendent of the Supersonics Division of the Aorodynamics Department in 1951 and was promoted to deputy chiof scientific officer in 1953. In 1956 he was promoted to chiof scientific officer and appointed head of the Aerodynamics Departmont. Since 1959 he has been serving as director general of sciontific research (air).

\section{Psychiatry at Leeds :}

Prof. M. Hamilton

DR. M. Hamiton has boon appointed to the Nuffield chair of psychiatry in the University of Loods, in suecession to the lato Prof. G. R. Hargreaves, from a date to be arranged. Dr. Hamilton was educated at the Central Foundation School, Cowper Street, University College and Univorsity College Hospital Medical School, London. He gained his M.B. and B.S.(London) in 1937. In 1946 he was awarded the Diploma in Psychological Medicine and a doctorate in medicine of the University of London in 1950. From 1934 until 1939, Dr. Hamilton worked in the field of general medicine and surgery and 